\title{
Pembuatan Floating Cage Berbahan PVC Sebagai Sarana Alternatif Usaha Mikro Budidaya Rumput Laut di Lingkungan Pattontongan Kabupaten Jeneponto
}

\author{
Wahyuddin Mustafa $^{1}{ }^{*}$, Syamsul Asri $^{1}$, Farianto Fachruddin ${ }^{1}$, Lukman Bochary ${ }^{1}$, Ganding \\ Sitepu ${ }^{1}$, Rosmani ${ }^{1}$, Moh.Rizal Firmansyah ${ }^{1}$, Hamzah $^{1}$ dan A.Ardianti ${ }^{1}$ \\ Departemen Teknik Perkapalan, Fakultas Teknik Universitas Hasanuddin ${ }^{1}$ \\ wahyuddinmustafa09@gmail.com*
}

\begin{abstract}
Abstrak
Masyarakat pesisir Jeneponto umumnya dan khususnya kelompok pebudidaya Pattontongan City, seluruh anggota menggunakan metode tali apung (long line) dalam budidaya rumput laut. Sebagai alternatif budidaya, perlu diperkenalkan metode-metode lain dalam upaya peningkatan kapasitas produksi. Salah satu metode yang dapat ditawarkan ke pebudidaya yaitu metode jaring/keramba apung (floating cage). Pengembangan metode floating cage oleh beberapa peneliti, terungkap bahwa rerata laju pertumbuhan rumput laut jauh lebih baik dibanding metode long line. Sebagai upaya awal dalam memperkenalkan metode ini adalah memperlihatkan bentuk atau model floating cage dan cara merakitnya, oleh karena itu dibutuhkan sebuah kegiatan pelatihan.

Pelatihan pembuatan floating cage di lakukan dengan dua pendekatan yaitu daring dan luring. Daring digunakan saat penjelasan materi dan luring saat perakitan dan peluncuran dan penambatan struktur floating cage. Struktur floating cage berbahan PVC, sehingga penyambungan struktur menggunakan teknik adhesive bonding berupa pengeleman. Karakteristik floating cage yang akan dijadikan objek praktek adalah dimensi 2 x 2 x 0,5 meter, daya apung berkisar $0,13 \mathrm{~m}^{3}$, berat struktur berkisar $43,18 \mathrm{~kg}$, dan displasemen berkisar $134,23 \mathrm{~kg}$.

Hasil yang diperoleh melalui pelatihan ini adalah peserta mampu (1) membaca desain floating cage, (2) melakukan penandaan (skala penuh) dan pemotongan pipa PVC, (3) melakukan perakitan awal dan perakitan akhir berupa penyambungan dengan teknik adhesive bonding, dan (4) melakukan proses peluncuran dan penambatan struktur floating cage. Manfaat yang dapat diperoleh peserta dari pelatihan ini adalah mampu membuat sendiri floating cage sehingga dapat menghemat biaya modal.

Kata Kunci: Long Line; Floating Cage; Perakitan; Penyambungan; Peluncuran.

Abstract

Generally, seaweed farmers on the Jeneponto coast, including the Pattontongan City seaweed farmer group, use the long line method instead of other seaweed cultivation methods. Alternative cultivation methods need to be introduced to increase their production capacity. One of the methods that can be offered to the farmers is the floating cage method. The development of the floating cage method by several researchers has revealed that seaweed's average growth rate is much better when compared with the long-line method. Initial attempts to introduce this method were carried out in the form of training by showing the shape or model of a floating cage and how to assemble it. Training is carried out online and offline. Online is used during material description while offline when the floating cage structure is assembled, launched, and anchored. The floating cage structure uses PVC as its material, while the adhesive bonding technique is used to connect the structural components. The floating cage model's characteristics have the dimensions of $2 \times 2 \times 0.5$ meters, with a buoyancy of $0.13 \mathrm{~m}^{3}$, the structure weight of $43.18 \mathrm{~kg}$, and the displacement of $134.23 \mathrm{~kg}$. After attending this training, participants were able to (1) read the floating cage design, (2) mark (full scale) and cut the PVC pipe structure, (3) do the initial assembly and the final assembly in the form of splicing using adhesive bonding techniques, and (4) perform the process of launching and anchoring the floating cage structure. The skill of making their floating cage will save costs when they are about to apply the floating cage method instead of the long line method in their seaweed cultivation
\end{abstract}

Keywords: Long Line; Floating Cage; Assembly Line; Joining; Launching. 


\section{Pendahuluan}

Salah satu kabupaten di wilayah Provinsi Sulawesi Selatan bagian selatan adalah Jeneponto. Posisi geografis berada antara $5^{\circ} 16^{\prime} 13^{\prime \prime}-5^{\circ} 39^{\prime} 35^{\prime \prime}$ Lintang Selatan dan antara 12 40 '19"$12^{\circ} 7$ ’31" Bujur Timur, berjarak $97 \mathrm{~km}$ dari Kota Makassar.

Wilayah bagian selatan Kabupaten Jeneponto memiliki garis pantai sepanjang $114 \mathrm{~km}$. Garis pantai sepanjang ini, dimanfaatkan sebagai usaha perikanan dan kawasan budidaya rumput laut. 7 (tujuh) dari 11 (sebelas) wilayah Kecamatan di Kabupaten Jeneponto telah dijadikan sebagai kawasan budidaya rumput laut.

Budidaya rumput laut merupakan usaha rakyat, dilakukan secara perseorangan maupun berkelompok. Pattotongan City merupakan kelompok pebudidaya rumput laut yang berada di Dusun Pattontongan Desa Biringkassi Kecamatan Binamu.

Sarana produksi yang digunakan adalah peralatan budidaya dan perahu. Peralatan budidaya yang dimaksud adalah: tali, pelampung, jangkar dan tempat jemuran. Perahu yang digunakan berukuran kecil atau yang biasanya disebut sampan yang terbuat dari fiberglass dan kayu. Metode pengembangan budidaya rumput laut oleh seluruh anggota menggunakan teknik longline dan belum teridentifikasi ada metode lain yang digunakan di seluruh wilayah Lingkungan Pattontongan.

Metode longline, adalah paling umum digunakan oleh pebudidaya di Indonesia, India, Malaysia, Tanzania, Vietnam, Brazil, Kenya and Madagascar, sebagaimana telah diungkapkan pada penelitian Luxton, (1993), Lirasan \& Twide (1993), Bindu (2011), Mollion \& Braud (1993), Ohno et al (1996), Hayashi et al (2007) dan Ask \& Azanza (2002) dalam Kasim M, dkk (2016). Metode longline seperti diperlihatkan pada Gambar 1.

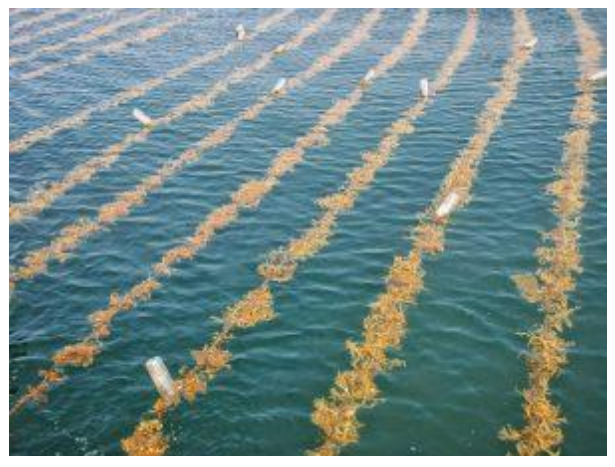

Gambar 1. Metode Longline dalam budidaya rumput laut

Walaupun metode longline banyak digunakan hampir seluruh pebudidaya di dunia akan tetapi menurut penelitian Kasim M, dkk (2016), menyimpulkan bahwa perbedaan metode budidaya menyebabkan perbedaan laju pertumbuhan (growth rate). Metode longline memberikan peluang kepada ikan-ikan (herbivorous fish) untuk memakan rumput laut (E. denticulatum). Rerata laju pertumbuhan (Average growth rate) metode longline lebih rendah dari metode floating cage dan mengurangi dampak dari serangan herbivorous fish. Menurut Kasim \& Asnani (2012) dalam 
Kasim M, dkk (2016) aktivitas Herbivorous fish dapat menurunkan total produksi rumput laut sampai $60 \%$.

Sebagai salah satu upaya peningkatan kapasitas produksi budidaya rumput, maka perlu diperkenalkan metode floating cage kepada pebudidaya di lingkungan Pattontongan. Sehubungan dengan pengenalan metode Floating Cage, maka permasalahan mitra di identifikasi sebagai berikut :

1. Mitra belum memahami konsep floating cage sebagai metode budidaya rumput laut.

2. Mitra belum memahami desain floating cage sebagai sarana budidaya rumput laut.

3. Mitra belum memahami teknik perakitan (assembly plan) floating cage.

4. Mitra belum memahami bahan dan peralatan yang digunakan dalam perakitan floating cage.

5. Mitra belum memahami Keselamatan dan Kesehatan Kerja (K3) dalam perakitan floating cage.

Mencermati permasalahan mitra di atas, maka diperlukan suatu kegiatan yang komprehensif, sistematis dan terstruktur untuk menjawab semua permasalahan tersebut, yaitu berupa kegiatan bimbingan dan pelatihan.

Target yang ingin dicapai melalui pelatihan ini adalah pebudidaya rumput laut memiliki kemampuan:

1. Mengenal material PVC sebagai alternatif bahan pembuatan floating Cage.

2. Mempunyai pengetahuan membaca gambar floating cage.

3. Mempunyai keterampilan kerja perakitan floating cage berlandaskan norma K3.

Dengan keterampilan yang dimiliki seperti yang telah disebutkan di atas pebudidaya mampu membuat sendiri sarana produksinya.

\section{Latar Belakang Teori}

\subsection{Floating Cage}

Floating cage merupakan struktur terapung di atas air, untuk memindahkannya perlu di tarik atau didorong menggunakan perahu atau manusia. Struktur floating cage terdiri dari apungan dan keranjang. Apungan dapat di buat dari bambu, kayu, plastik PVC, fiberglass dan logam. Keranjang dapat di buat dari jaring.

\subsection{Konsep Desain}

Konsep desain floating cage yang akan digunakan untuk pesisir Pattontongan, mempertimbangkan:

1. fungsi

floating cage berfungsi sebagai sarana budidaya rumput laut. oleh karena floating cage dibangun sebagai alternatif pengganti metode long line, maka floating cage harus mampu minimal menampung $75 \mathrm{~kg}$ hasil rumput laut. $75 \mathrm{~kg}$ ini setara dengan berat hasil panen untuk satu bentangan tali.

2. aktivitas budidaya

aktifitas budidaya rumput laut menggunakan floating cage :

- menabur benih/bibit. 
- mentransportasi floating cage ke tempat budidaya (seaweed ground)

- memanen rumput laut

Kedalaman adalah salah satu faktor yang berpengaruh terhadap penyerapan cahaya oleh rumput laut, kedalaman yang baik untuk pertumbuhan rumput laut adalah 0,3-0,6 m, ditjenkanbud dalam Nurafiat A.A.Y (2020). Aktivitas penaburan benih/bibit akan mudah jika kedalaman floating cage sesuai, sehingga tinggi bibir floating cage tidak melebihi dada pebudidaya.

Simpulan dimensi awal berdasarkan pertimbangan kapasitas harus lebih besar sama dengan 75 kg dan aktifitas budidaya adalah: dimensi 2 × 2 x 0,5 meter.

Berdasarkan analisis berat dan hidrostatika, karakteristik floating cage, seperti terlihat pada Tabel 1.

Tabel 1. Karakteristik berat dan hidrostatika floating cage

\begin{tabular}{crrrr}
\hline \multirow{2}{*}{ Nama } & \multicolumn{4}{c}{ Karakteristik Berat dan Hidrostatika } \\
\cline { 2 - 5 } & $\begin{array}{c}\text { Daya Apung } \\
\left(\mathrm{m}^{3}\right)\end{array}$ & $\begin{array}{c}\text { Berat Struktur } \\
(\mathrm{kg})\end{array}$ & $\begin{array}{c}\text { Displasemen } \\
(\mathrm{kg})\end{array}$ & $\begin{array}{c}\text { Kapasitas muat } \\
(\mathrm{kg})\end{array}$ \\
\hline Floating cage & 0.13 & 43.18 & 134.23 & 91.04 \\
\hline
\end{tabular}

Sumber : Nurafiat A.A.Y, 2020

\subsection{Struktur Floating Cage}

Struktur floating cage berbahan PVC. elemen struktur terdiri dari pipa (kaki dan pelintang) dan sambungan ( $\mathrm{T}$ dan elbow $90^{\circ}$ ). Penutup dan dinding struktur menggunakan jaring, pengikatan jaring ke struktur menggunakan tali dan atau kabel ties. Gambar 2, memperlihatkan desain 2D dan 3D struktur floating cage .

\subsection{Perakitan Floating Cage}

Perakitan floating cage dapat dilakukan dengan berbagai macam urutan kegiatan atau skenario (assembly plan), dapat dengan pendekatan seri dan paralel, tergantung sumber daya.

1. Skenario pertama :

Floating cage di bagi menjadi 2 (dua) sub-modul, yaitu sub-modul dasar dan sub-modul atas. kedua sub-modul dapat kerjakan bersamaan atau seri, setelah kedua sub-modul selesai dapat dirakit menjadi modul.

2. Skenario kedua :

Floating cage di bagi menjadi 4 (empat) sub-modul, yaitu sub-modul bagian depan, belakang, kiri dan kanan. Sub-modul kanan di rakit ke sub-modul belakang, selanjutnya di rakit ke sub-modul kiri membetuk sub-modul menyerupai huruf $U$ dan terakhir sub-modul depan di rakit ke sub-modul yang berbentuk $\mathrm{U}$.

Penyambungan komponen struktur floating cage PVC menggunakan teknik penyambungan adhesive bonding yaitu berupa penggunaan lem (J. R. Weitzenböck, 2012) (Pipe Association, 2013 ) (Jordan Bunker, 2018). 


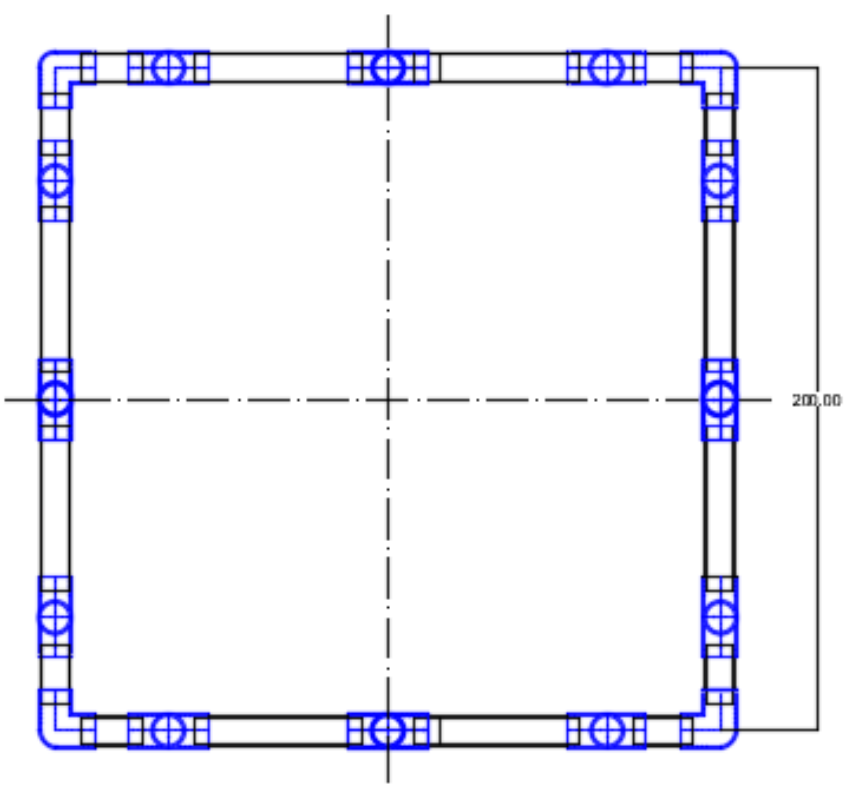

$\mathrm{CL}$
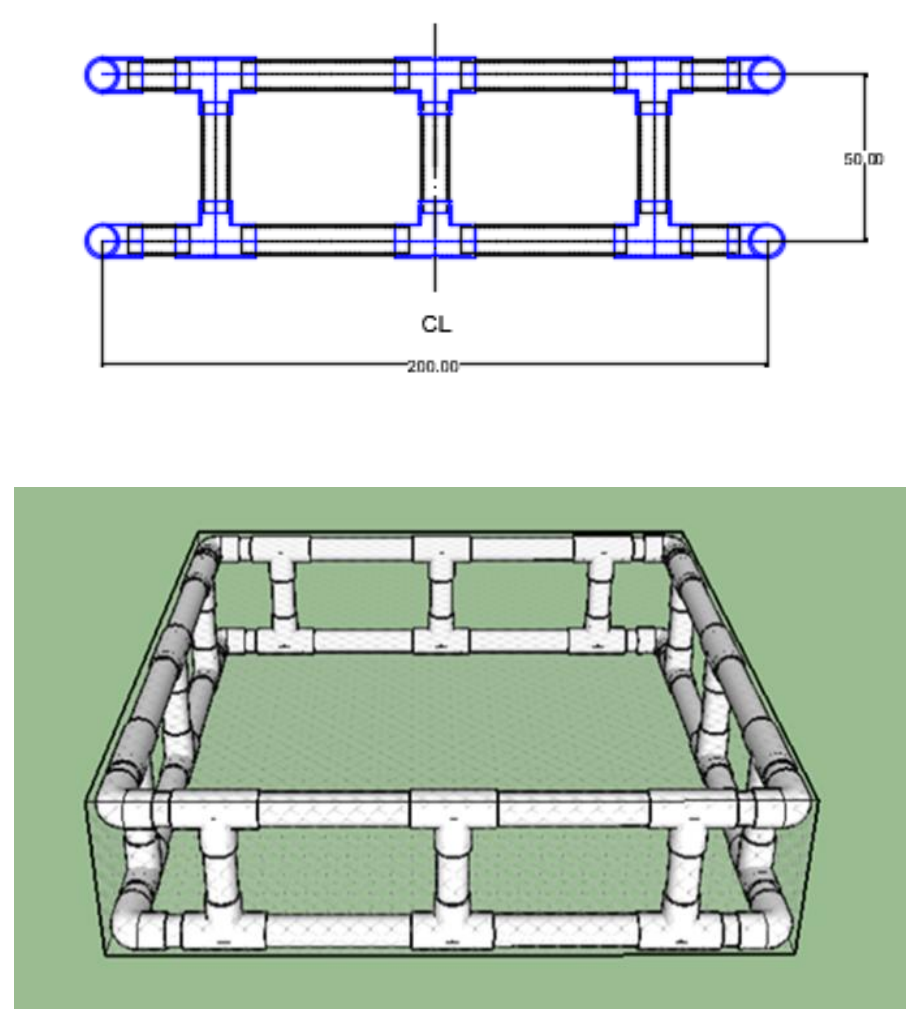

Gambar 2. Desain struktur floating cage ; tampilan 2D dan 3D

Sumber: Nurafiat A.A.Y, 2020

\section{Metode}


Metode disusun guna menjawab permasalahan sebagaimana dijelaskan pada pendahuluan maka solusi yang ditawarkan berupa pelatihan dan pembimbingan kepada pebudidaya, dengan tahapan sebagai berikut:

1. Tahap Persiapan; tahapan ini meliputi pemilihan desain floating cage yang akan digunakan sebagai objek kerja, penentuan jumlah kebutuhan bahan dan peralatan kerja $P V C$, dan penyusunan jadwal pelaksanaan kegiatan

2. Tahap Pelaksanaan;.tahapan ini meliputi pemberian teori tentang desain floating cage, pemindahan desain floating cage ke skala penuh, dan teknik perakitan dengan penyambungan adhesive bonding. Praktek kerja meliputi pemotongan pipa berdasarkan MLC (daftar material komponen) dan penerapan teknik penyambungan adhesive bonding..

3. Tahap Evaluasi; tahapan ini meliputi memeriksa dimensi floating cage dan daya apung pada muatan kosong.

Tahapan ini dilaksanakan di dua tempat yaitu di Labo Produksi Kapal Unhas dan Rumah Produksi Perahu Fiberglass Unhas-JICA di Lingkungan Pattontongan Kecamatan Binamu Kabupaten Jeneponto.

\section{Hasil dan Diskusi}

Floating Cage menjadi sebuah gagasan baru atau metode baru dalam pengembangan budidaya rumput laut di Lingkungan Pattontongan khusunya bagi kelompok Pattontongan City. Oleh karena itu telah diadakan kegiatan sebelumnya untuk memberikan gambaran dan penjelasan terkait floating cage, berupa kegiatan pengenalan apa dan bagaimana floating cage sebagai sarana budidaya rumput laut, kegiatan ini diadakan sekitar bulan Maret 2020. Berdasarkan respon dan perhatian pebudidaya terhadap sarana alternatif ini, maka kegiatan dilanjutkan berupa pelatihan pembuatan floating cage.

Kegiatan pelatihan dibagi menjadi tiga tahap. Kegiatan tahap pertama adalah pengadaan bahan yang akan di gunakan sebagai media pelatihan dan memastikan bahan tersedia di lokasi pelatihan. Bahan-bahan perakitan floating cage seperti terlihat di Gambar 3.
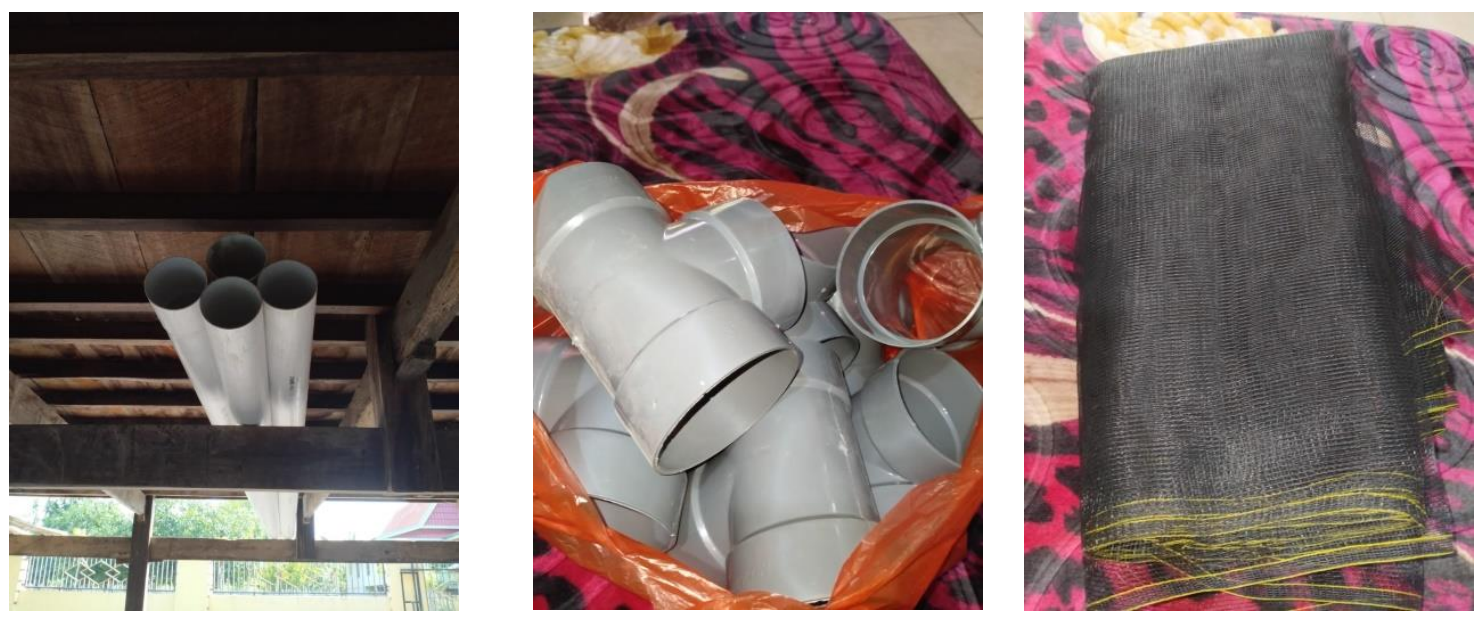

Gambar 3. Bahan-bahan struktur floating cage 
Kegiatan tahap kedua adalah pelaksanaan berupa penjelasan mencakup bahan dan peralatan yang digunakan, desain, skenario perakitan (assembly plan) dan teknik penyambungan dan pengikatan struktur floating cage. Kegiatan pelaksanaan ini di bagi dua pendekatan yaitu sacara daring dan luring. Kegiatan daring dilaksanakan pada malam hari tepatnya hari Sabtu, tanggal 26 September 2020. Visualisasi kegiatan daring seperti terlihat pada Gambar 4.
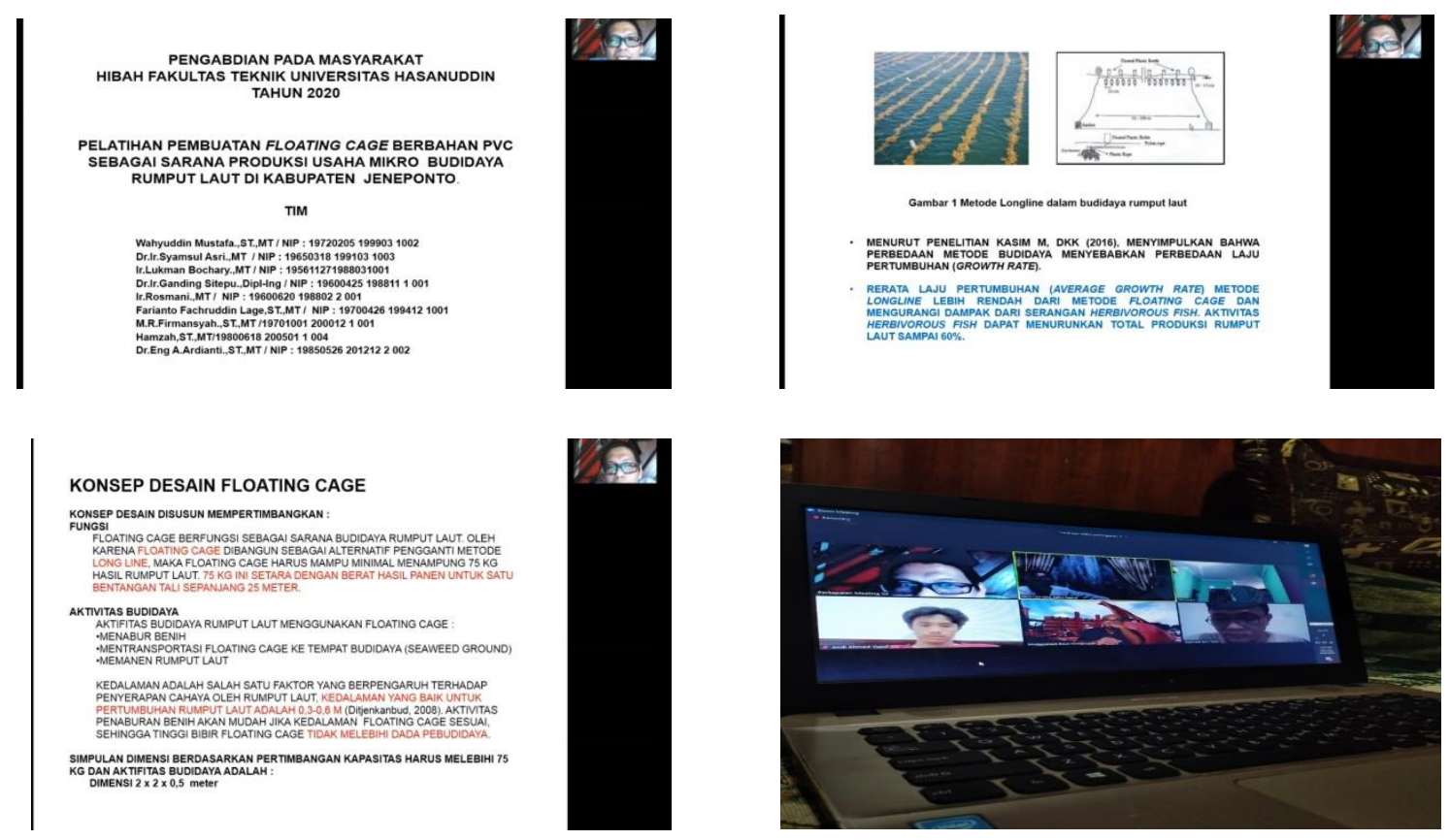

Gambar 4. Penjelasan desain dan teknik perakitan struktur floating cage secara daring

Kegiatan luring dilaksanakan pada hari Minggu, tanggal 27 September 2020, mencakup kegiatan:

1. Mengecek kembali jumlah bahan sesuai dengan MLS (material list by system).

2. Membaca desain struktur.

3. Membuat penandaan skala penuh pada struktur.

4. Melakukan pemotongan pipa PVC, berdasarkan MLC (material list by component).

5. Melakukan perakitan awal struktur dengan berdasarkan urutan/skenario perakitan (assembly plan).

6. Mengontrol/mengecek dimensi struktur sebelum di lem.

7. Melakukan penyambungan struktur dengan teknik adhesive bonding.

8. Memotong jaring dan partisi/sekat struktur.

9. Memasang jaring dan partisi struktur.

10. Pengecekan akhir dimensi dan kelengkapan struktur.

11. Proses peluncuran/pengangkatan struktur ke lokasi.

12. Penambatan struktur di lokasi (seaweed ground).

Visualisasi seluruh kegiatan pelaksanaan di atas, seperti terlihat pada Gambar 5. 

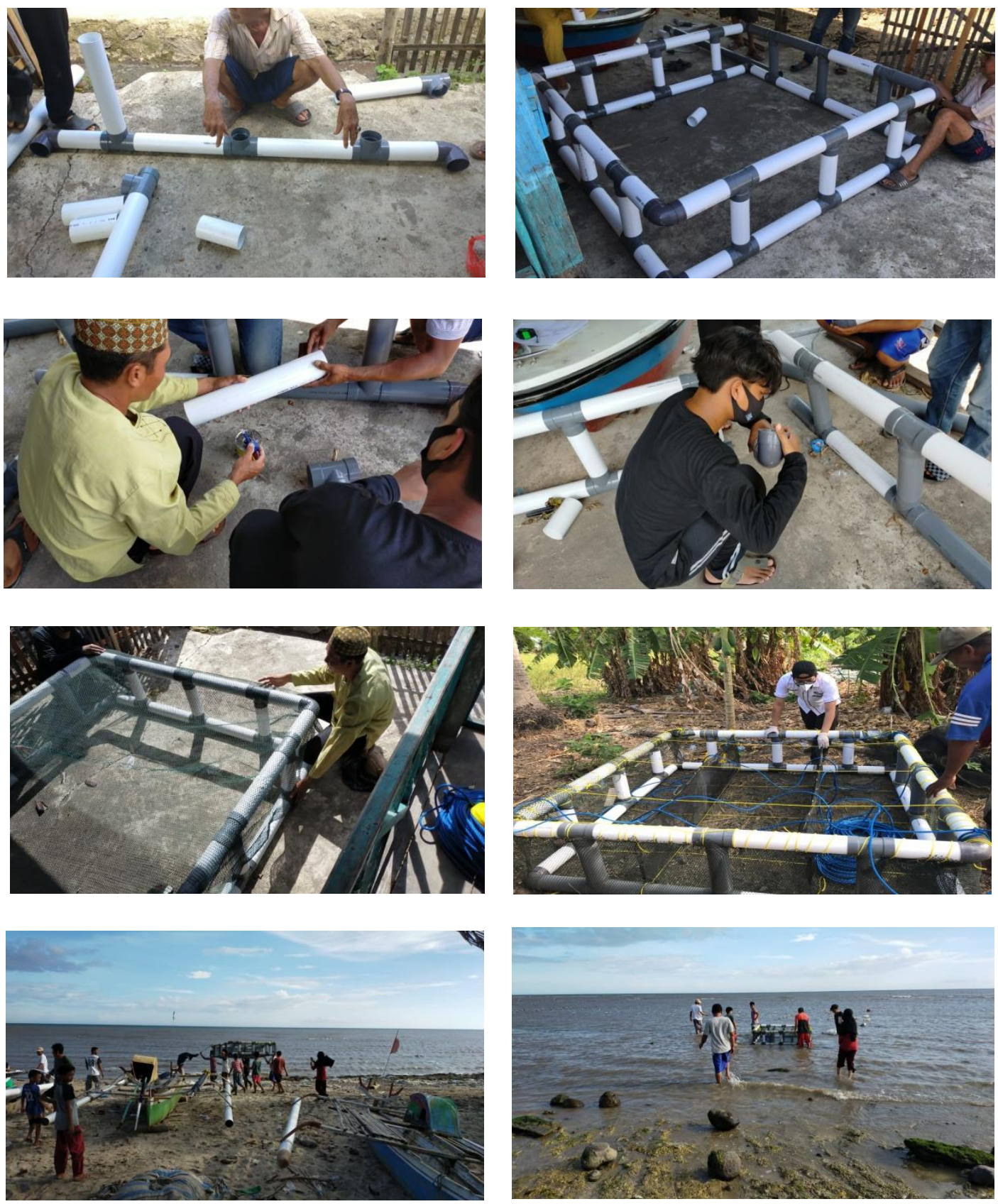

Gambar 5. Pemotongan, perakitan, peluncuran dan penambatan struktur floating cage

Tahap ketiga berupa evaluasi, yaitu melakukan pengecekan daya apung struktur pada muatan kosong. Hasil pemantauan memperlihatkan bahwa sarat menunjukkan sekitar kedalaman kurang lebih $10 \mathrm{~cm}$, hal ini tidak jauh berbeda dengan perencanaan, diharapkan struktur floating cage mampu menampung sekitar $100-150 \mathrm{~kg}$ rumput laut. Evaluasi setelah penggunaan selama 2 (dua) minggu, seperti terlihat pada Gambar 6. 

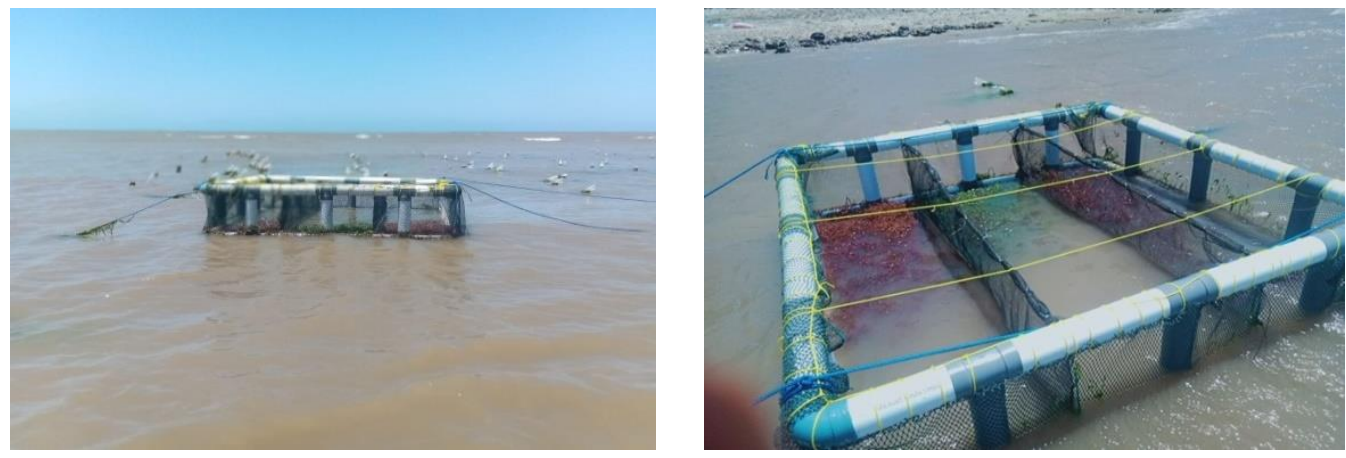

Gambar 6. Kondisi floating cage setelah penggunaan selama 2 (dua) minggu

Beberapa hal yang menjadi topik diskusi pada pelatihan yaitu:

1. Penandaan dan Pemotongan Struktur Pipa

Saat penandaan dan pemotongan, peserta membuat kelalaian yaitu tidak melakukan pengecekan terhadap MLC (material by component) sehingga beberapa komponen salah potong dan memerlukan penambahan material pipa.

2. Perakitan dan Penyambungan

Perakitan dilakukan dua kali yaitu perakitan awal dan perakitan akhir. Perakitan awal dimaksudkan untuk menyusun potongan-potongan pipa menjadi struktur dan dilakukan pengecekan dimensi tinggi dan lebar dan panjang serta diagonal struktur.

Saat perakitan akhir di lakukan penyambungan dengan lem, terjadi peserta kembali melakukan kelalaian dalam membaca skenario perakitan sehingga salah satu modul mengalami kesulitan saat akan disatukan, walaupun tidak menyebabkan penambahan material tetapi ini menjadi catatan penting untuk selalu berpatokan pada skenario perakitan, oleh karena teknik penyambungan dengan adhesive bonding (lem) bila terjadi kesalahan maka struktur harus di bongkar dan mengganti dengan bahan yang baru.

3. Peluncuran dan penambatan

Proses peluncuran di lakukan dengan teknik pengangkatan karena berat struktur relatif ringan dan membutuhkan minimal 4 (orang). Sebelum penambatan di lakukan pengecekan daya apung struktur saat muatan kosong, hal ini untuk memastikan sarat yang tercapai sesuai dengan desain. Penambatan struktur menggunakan jangkar yang sebelumnya digunakan untuk teknik long line, ditambat pada 4 (empat) sudut struktur.

\section{Kesimpulan}

Setelah dilakukan pelatihan dan bimbingan kepada pebudidaya tentang pembuatan perahu dapat disimpulkan:

1. Peserta mampu membaca desain floating cage.

2. Peserta mampu melakukan penandaan (skala penuh) dan pemotongan pipa PVC.

3. Peserta mampu melakukan perakitan awal dan perakitan akhir berupa penyambungan dengan teknik adhesive bonding.

4. Peserta mampu melakukan proses peluncuran dan penambatan struktur floating cage. . 


\section{Ucapan Terimakasih}

Terimakasih kepada semua pihak yang mendukung terlaksananya kegiatan ini terutama Dekan Fakultas Teknik atas dana hibah pengabdian Fakultas Teknik dan kelompok pebudidaya "Pattontongan City" di Lingkungan Pattontongan Kecamatan Binamu Kabupaten Jeneponto dan alumni prodi teknik perkapalan Unhas yaitu A.Ahmad Yusuf Nurafiat.,ST, Muh. Alfalaq Firdaus.,ST dan Firda Rahayu Hairul.,ST

\section{Daftar Pustaka}

Budiyanto, Kasim F., Abadi S. Y., 2019 Growth and carrageenan content of local and tissue culture seed of Kappaphycus alvarezii cultivated in floating cage. AACL Bioflux 12(1):167178.

Jordan Bunker, 2018, PVC + Pipe Engineer; Put Together Cool, Easy, Maker-Friendly Stuff, Rockport Publishers, Beverly, USA.

J. R. Weitzenböck, 2012, Introduction to using Adhesives in Marine and Offshore Engineering; Adhesives in marine engineering ed. J. R. Weitzenböck chapter 1 pp 1-14.

Kasim M., Mustafa A., Munier T., 2016 The growth rate of seaweed (Eucheuma denticulatum) cultivated in longline and floating cage. AACL Bioflux 9(2):291-299.

Kasim M, et all, 2017, New Methods on Cultivation of Eucheuma denticulatum and Kappahycus alvarezii in Indonesia,J.Fish.Aquat.Sci.,12:207-217.

Ma'ruf Kasim, Ahmad Mustafa.,2017, Comparison growth of Kappaphycus alvarezii (Rhodophyta, Solieriaceae) cultivation in floating cage and longline in Indonesia, Aquaculture Reports 6 (2017) 49-55.

Nurafiat A.A.Y, 2020, Desain Produksi dan Kelayakan Investasi Floating Cage sebagai Sarana Alternatif Budidaya Rumput Laut, Skripsi Prodi Teknik Perkapalan Universitas Hasanuddin, Gowa.

Pipe Association, 2013, Handbook of PVC Pipe Design and Construction, Industrial Press, New York. 